\title{
Leaf thickness and gas exchange are indicators of drought stress tolerance of sugarcane
}

\author{
Sebastião de Oliveira Maia Júnior ${ }^{1 *}$, Jailma Ribeiro de Andrade ${ }^{1}$, Claudiana Moura dos Santos ${ }^{1}$, \\ João Antônio Carvalho Silva', Karolyne Priscila Oliveira dos Santos ${ }^{1}$, José Vieira Silva², \\ Lauricio Endres ${ }^{1}$
}

${ }^{1}$ Laboratory of Plant Physiology, Agricultural Sciences Center, Federal University of Alagoas - Campus Delza Gitaí, BR 104 Norte, Km 85. Rio Largo - AL, Brazil, '2Federal University of Alagoas, Campus Arapiraca. Av. Manoel Severino Barbosa, s/n. Bom Sucesso, CEP 57309-005, Arapiraca, AL, Brazil

\section{A B S T R A C T}

\begin{abstract}
The frequent occurrence of prolonged droughts has become a very negative factor in the sugarcane crop production worldwide. Ratoon sugarcane, after second crop cycle, can response to drought stress is different as first crop cycle. Thus, this study aimed to investigate the biometric and physiological responses of sugarcane varieties under drought stress conditions of ratoon crop sugarcane. Our hypothesis is that some biometric and physiological characteristics of sugarcane are correlated with its drought tolerance. Six sugarcane varieties were used: 1-RB72910, 2-RB99382, 3-RB72454, 4-RB92579, 5-RB855536 and 6-RB931011, and three water treatments based on soil available water content (SAWC) and defined as: 1-control, 80 to 100\% SAWC; 2-moderate water stress, 40 to $60 \%$ SAWC and 3 -severe water stress, 0 to $20 \%$ SAWC. The RB92579 variety was the most tolerant to drought, with less alteration in its biometric and physiological characteristics under drought stress. On the other hand, RB72454 variety was the most affected by drought stress, with high reduction in gas exchange and plant growth. Sugarcane leaf width, specific leaf area, stomatal conductance, transpiration, photosynthesis and carboxylation efficiency were quite sensitive to changes in soil moisture and can be used by breeding programs to discriminate sugarcane varieties more tolerant to drought stress.
\end{abstract}

Keywords: Photosynthesis; Saccharum spp.; Specific leaf area; stomatal control; water deficit

\section{INTRODUCTION}

Sugarcane (Saccharum spp.) is a crop of great economic importance worldwide due to its use as a raw material for the food industry and the production of renewable biofuel. It is cultivated in several countries, including tropical and subtropical regions, where the largest producers are Brazil, India and China (Silva et al., 2013, Zhao and Li, 2015). In the 2018-2019 harvest, Brazil has a planted area of 8.61 million hectares and an estimated production of 625.96 million tons. Much of this planted area is subject to water deficit incidence, mainly in the Northeast region of Brazil (Vieira et al., 2014; Conab, 2018).

Water deficiency has been identified as one of the environmental factors responsible for the largest reductions in sugarcane production, even in rainy regions, but poorly distributed throughout the year (Ribeiro et al., 2013; Vieira et al., 2014). Thus, one of the major challenges for farmers has been to increase crop yield in regions subject to drought stress. In this aspect, the selection of varieties more tolerant to the drought stress has become fundamental to make the crop viable in these regions (Silva et al., 2011; 2013).

Under drought stress, plants can increase leaf thickness as a mechanism to keep more leaf water content (Lopez et al., 1997; Trujillo et al., 2013). Moreover, under these conditions, plants tend to close stomatal in an attempt to restrict water loss through transpiration (Machado et al., 2009; Medeiros et al., 2013; Ribeiro et al., 2013), which also reduces the photosynthesis (Endres et al., 2010; Sales et al., 2012). Thus, it can affect sugarcane growth and consequently crop yield (Machado et al., 2009).

Drought stress also may induce serious damages to the photosynthetic apparatus (Silva et al., 2013). These damages

\footnotetext{
*Corresponding author:

Sebastião de Oliveira Maia Júnior, Laboratory of Plant Physiology, Agricultural Sciences Center, Federal University of Alagoas - Campus
} Delza Gitaí, BR 104 Norte, Km 85. Rio Largo - AL, Brazil. E-mail: juniormaiagrari@hotmail.com

Received: 01 December 2018; $\quad$ Accepted: 21 January 2019 
can be interpreted by the $\mathrm{Fv} / \mathrm{Fo}$ ratio that estimates the maximum primary PSII yield, it provides an effective estimate of photosynthetic capacity (Puteh et al., 2013), as reported in sorghum (Peixoto et al., 2002) and barley (Kalaji et al., 2011).

Several studies have been carried out to select sugarcane varieties more tolerant to drought stress. However, most of these experiments were conducted with plant-cane in a greenhouse with small pots or containers up to 30 liters in capacity (Machado et al., 2009; Medeiros et al., 2013), and this may limit root growth due to the limited volume of soil (Gonçalves et al., 2010). For that reason, the use of large containers in which sugarcane root can growth better, even in ratoon crop, may respond different to observed in greenhouse plant-cane crop.

Our hypothesis is that sugarcane biometric a physiological alteration under drought stress in plant-crop; first crop cycle, such as reductions in plant height and gas exchange (Gonçalves et al., 2010; Medeiros et al., 2013) will also happen in ratoon-crop; second cycle. Thus, this study aimed to quantify biometric and physiological responses of sugarcane varieties in ratoon crop under drought stress.

This study also aims to contribute to characterize new characteristics to be used in the selection of varieties more tolerant to drought, that can be used the crop breeding programs.

\section{MATERIAL AND METHODS}

The experiment was conducted under geodesic coordinates $9^{\circ} 28^{\prime} 00^{\prime \prime} \mathrm{S}, 35^{\circ} 49^{\prime} 34^{\prime \prime} \mathrm{W}, 131 \mathrm{~m}$ above sea level. The experimental design was in randomized blocks, with factorial arrangement $6 \times 3$ and four replications. Six sugarcane varieties and three water regimes were used, totaling 72 experimental plots. Sugarcane varieties used were RB72910, RB99382, RB72454, RB92579, RB855536 and RB931011. The water treatments were based on the soil available water capacity (SAWC) and defined as: control, 80 to $100 \%$ (SAWC); moderate water stress, 40 $60 \%$ (SAWC) and severe water stress, 0 to 20\% (SAWC). The experimental plot consisted of a cylindrical vessel (average diameter of $0.485 \mathrm{~m}$, height $0.99 \mathrm{~m}$ and capacity of 185 liters), filled with $250 \mathrm{~kg}$ of pulverized, sieved and homogenized soil. All containers were kept in the open air, spaced $1 \mathrm{~m}$ apart, in both rows and rows.

The soil used was a cohesive Yellow Latosol. Physicochemical analyses were performed according to methodology of Embrapa (1997), and the water retention curve was estimated using the methodology of Richards (1965), which results are shown in Table 1.
Table 1:Physicochemical analyses of the soil used in the experiment

\begin{tabular}{|c|c|}
\hline \multicolumn{2}{|l|}{ Analysis soil } \\
\hline \multicolumn{2}{|c|}{ Chemical } \\
\hline Electrical conductivity & $0.32 \mathrm{dS} \mathrm{m}^{-1}$ \\
\hline $\mathrm{pH}$ & 6.3 \\
\hline $\mathrm{Ca}^{2+}$ & $7.61 \mathrm{cmolc} \mathrm{kg}^{-1}$ \\
\hline $\mathrm{Mg}^{2+}$ & $4.41 \mathrm{cmolc} \mathrm{kg}^{-1}$ \\
\hline $\mathrm{Na}^{+}$ & $0.26 \mathrm{cmolc} \mathrm{kg}^{-1}$ \\
\hline $\mathrm{K}^{+}$ & $0.18 \mathrm{cmolc} \mathrm{kg}^{-1}$ \\
\hline$P$ & $49 \mathrm{mg} \mathrm{kg}^{-1}$ \\
\hline $\mathrm{Al}^{3+}$ & $0.00 \mathrm{cmolc} \mathrm{kg}^{-1}$ \\
\hline Organic matter & $35.60 \mathrm{~g} \mathrm{~kg}^{-1}$ \\
\hline \multicolumn{2}{|c|}{ Physical } \\
\hline Total porosity & $56.2 \%$ \\
\hline Real density & $1.17 \mathrm{~g} \mathrm{~cm}^{-3}$ \\
\hline Sand & $637.6 \mathrm{~g} \mathrm{~kg}^{-1}$ \\
\hline Silt & $205.9 \mathrm{~g} \mathrm{~kg}^{-1}$ \\
\hline Clay & $156.5 \mathrm{~g} \mathrm{~kg}^{-1}$ \\
\hline Textural classification & Franco clay sandy \\
\hline Soil Tension (MPa) & Water content (\%) \\
\hline 0.033 & 27.72 \\
\hline 1.5 & 14.76 \\
\hline Available Water & 12.96 \\
\hline
\end{tabular}

The sugarcane billets used for planting were standardized taking into account age (12 months), stalk region and health status (without pathologies). In order to guarantee better homogeneity of seedlings, smaller single budded sets were previously planted in plastic trays in greenhouse until seedlings had three leaves, suitable for transplanting. After 30 days of planting, three seedlings of uniform size were selected and transplanted for each container.

At 240 days after planting, the plant-cane was harvested, beginning the second cycle. Subsequently, containers were irrigated near the field capacity until the moment of implantation of the water regimes that began 60 days after harvesting of plant-cane. Tillering thinning was performed, leaving six plants of uniform size in each container. At 30 days after harvest, the fertilization was done according to Vitti et al. (2013), based on the soil chemical analysis.

During the water stress period, soil moisture was monitored in each container by soil moisture monitoring probe system (Moisture Meter PR2, Delta T Devices, England), which evaluates moisture every $0.1 \mathrm{~m}$ to depth of $0.4 \mathrm{~m}$. Water was replaced by a pressurized irrigation system, with one emitter per plot, leaving each water treatment in its moisture range (Fig. 1a). Climatic data for the experimental period were obtained by an automatic agrometeorological station located approximately $200 \mathrm{~m}$ from the experiment. Data were recorded every ten minutes, obtaining information on rainfall (Fig. 1b), mean air temperature (Fig. 1c) and relative air humidity (Fig. 1d). 


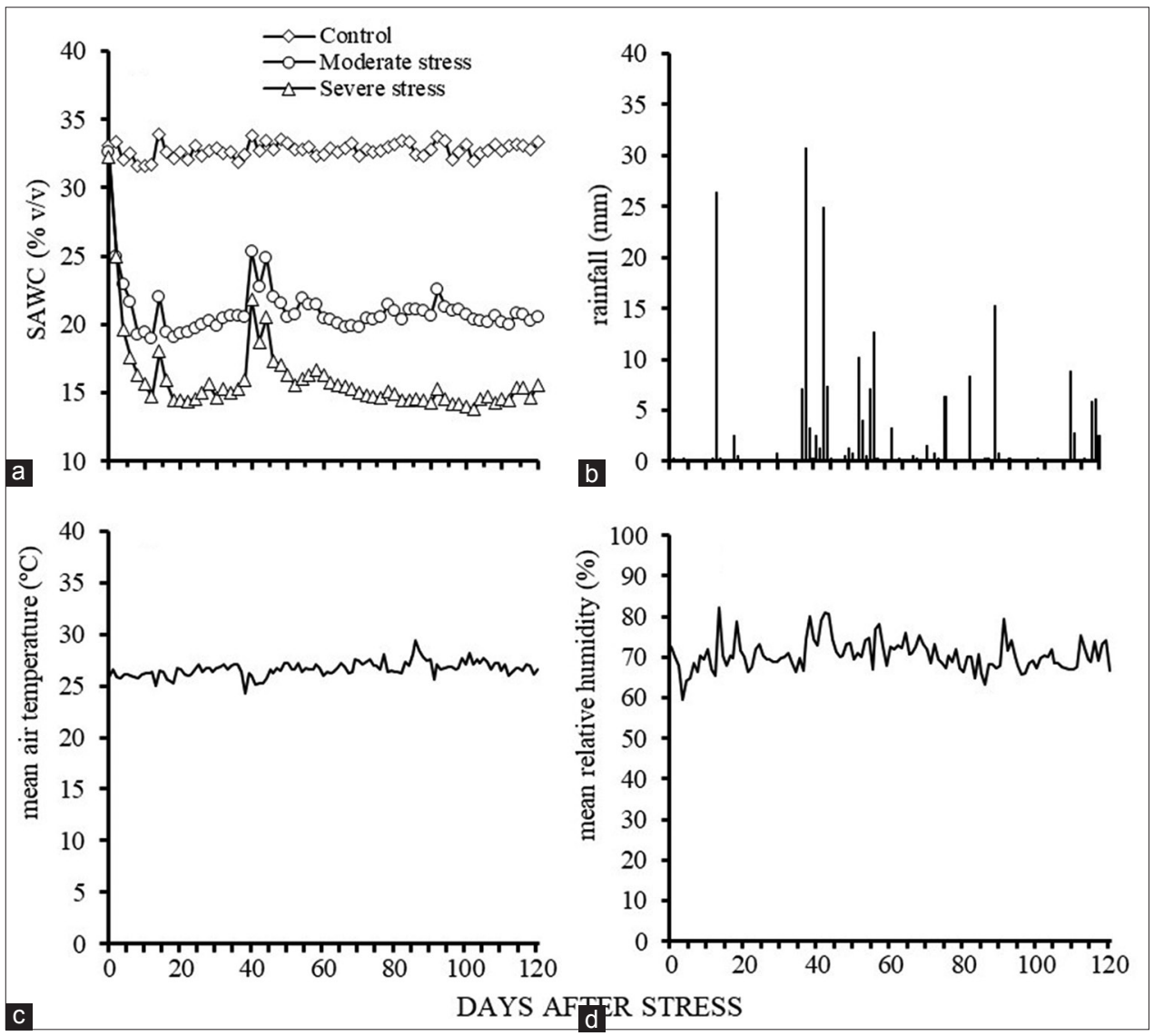

Fig 1. Soil moisture with sugarcane varieties submitted to drought stress in the second cycle (a), rainfall (b), mean air temperature (c) and mean air relative humidity $(\mathrm{d})$ during the experimental period.

All physiological and biometric evaluations were performed in the sugarcane ratoon, second cycle, as described below.

\section{Physiological changes}

The following physiological evaluations were carried out at 82 days of ratoon crop, 22 days after the beginning of the water stress: leaf water potential, gas exchanges and primary photochemical efficiency of PSII (Fv/Fo).

The leaf water potential $\left(\Psi_{\mathrm{w}}\right)$ was evaluated between 08:00 am and 11:00 am, determined in the middle part of leaf +1 , using a Scholander pressure chamber (SoilMoisture Equipment, Santa Barbara, USA).

Gas exchange measurements were quantified in the middle third of leaf +1 with gas analyzer model Li-6400XT (Licor, USA) between 08:00 am and 10:00 am. The equipment measured stomatal conductance $(g s)$, transpiration $(E)$, internal carbon concentration $(C \imath)$, net photosynthesis $(A)$, and instantaneous carboxylation efficiency relating net photosynthesis to internal $\mathrm{CO}_{2}$ concentration $(A / C \imath)$.

Measurements of photosystem II primary photochemical efficiency (Fv/Fo) were quantified between 12:00 am and
1:00 pm on leaves +1 pre-adapted to the dark $(\sim 30 \mathrm{~min})$ with the use of specific clips placed in the middle region of leaves, avoiding the central vein, using a modulated light fluorometer (PAM 2500, WALZ) following procedures proposed by Maxwell and Johnson (2000).

\section{Biometric changes}

At 180 days of ratoon-crop, 120 days of water stress, the following biometric characteristics were quantified: plant height $(\mathrm{cm})$, number of expanded leaves with at least $20 \%$ green area, length and width of leaf $+3(\mathrm{~cm})$ according to the Kuijper classification (Van Dillewijn, 1952). From the width and length of leaf +3 and the number of leaves, the leaf area $\left(\mathrm{cm}^{2}\right)$ was calculated using method described by Hermann and Câmara (1999).

Plants were then collected, separated in leaves and stalks, and dried in an oven with forced air circulation at $70{ }^{\circ} \mathrm{C}$ until reaching constant weight.

Leaf dry biomass and leaf area were used to quantify the Specific leaf area: SLA=LA/LDM $\left(\mathrm{cm}^{2} \mathrm{~g}^{-1}\right)$, where: $\mathrm{LA}=$ Leaf area; $\mathrm{LDM}=$ Leaf dry biomass. 
Table 2: Summary of the analysis of variance of physiological variables: leaf water potential ( $\Psi w)$, stomatal conductance (gs), transpiration $(E)$, internal $\mathrm{CO}_{2}$ concentration $(C i)$, photosynthesis $(A)$, carboxylation efficiency $(A / C i)$, and primary photochemical efficiency of photosystem II (Fv/Fo) in sugarcane varieties under different water treatments: control, moderate stress and severe stress

\begin{tabular}{lcccccccc} 
SV & DF & \multicolumn{9}{c}{ Mean squares } \\
\cline { 2 - 8 } & & $\Psi w$ & $g s$ & $E$ & $C i$ & $A$ & $A / C i$ & Fv/Fo \\
\hline W & 2 & $2.301^{*}$ & $0.34^{*}$ & $46.20^{*}$ & $5.259 .76^{*}$ & $1.935 .9^{*}$ & $0.06^{*}$ & $3.04^{*}$ \\
V & 5 & $0.096^{*}$ & $0.00^{*}$ & $0.84^{*}$ & $2.040 .31^{*}$ & $71.43^{*}$ & $0.008^{*}$ & $0.35^{*}$ \\
(W x V) & 10 & $0.035^{\text {ns }}$ & $0.01^{*}$ & $1.11^{*}$ & $1.077 .82^{*}$ & $40.67^{*}$ & $0.003^{*}$ & $0.29^{*}$ \\
Error & 34 & 0.040 & 0.00 & 0.41 & 453.53 & 16.68 & 0.000 & 0.03 \\
\hline
\end{tabular}

SV: Sources of variation; DF: degrees of freedom; W: Water treatments; V: Varieties. *: significant at P<0.05 by Tukey test; ns: non-significant

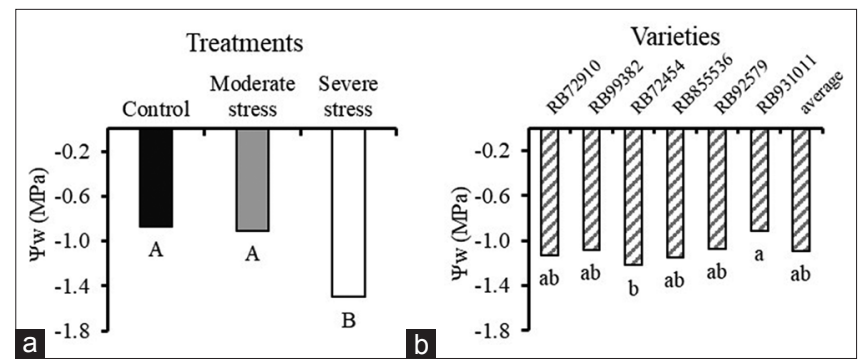

Fig 2. Leaf water potential ( $a$ and $b$ ) in sugarcane varieties under different water treatments: control, moderate stress and severe stress. Different capital letters indicate significant differences between water treatments; different lowercase letters indicate significant differences between varieties by Tukey test $(p<0.05)$.

\section{Statistical analysis}

Data were submitted to analysis of variance by the F test, and when significant difference was detected, differences among means were tested using the Tukey test at $\mathrm{p}<0.05$. Variables that had interaction between factors were submitted to Principal Component Analysis (PCA), which allows determining their relationships with varieties in each water condition.

\section{RESULTS}

\section{Physiological changes}

Water treatments affected all physiological variables (Table 2). In addition, stomatal conductance, transpiration, $\mathrm{Fv} / \mathrm{Fo}$, internal $\mathrm{CO}_{2}$ concentration, photosynthesis and instantaneous carboxylation efficiency interaction effect between water treatments and varieties.

The leaf water potential was $40 \%$ lower in plants under severe water stress than in moderate stress and control plants (Fig. 2a). Among varieties, RB931011 variety maintained the highest water potential, while RB72454 variety had the lowest potential (Fig. 2b).

Stomatal conductance varied greatly among varieties under water stress (Fig. 3a), RB72454 and RB931011 varieties were the most affected by severe stress, reducing gs about 94.3 and $93.2 \%$, respectively. On the other hand, the RB92579 and RB72910 varieties had the lowest reductions, approximately 55.1 and $67.8 \%$, respectively (Fig. 3a).

Leaf transpiration presented similar behavior with gs in severe stress among the varieties. The transpiration was lower in the RB72454 and RB931011 varieties, about 90.3 and $87.3 \%$, respectively (Fig. 3b). Meanwhile, in relation to control treatments, transpiration was less affected in the RB92579 and RB72910 varieties, which presented reductions of 48.9 and $62.7 \%$, respectively (Fig. 3b).

In some varieties, internal $\mathrm{CO}_{2}$ concentration $(C \imath)$ decreased with increasing stress, as in RB92579 and RB72910 varieties (Fig. 3c), while in others, there was a reduction of $C i$ under moderate stress and again an increase when under severe stress, as in RB72454 and RB931011 varieties (Fig. 3c).

The RB92579 variety reduced less photosynthesis under severe stress, while RB72454 variety showed the greatest decrease in photosynthesis, with $89.9 \%$ reduction (Fig. 3d). The RB92579 variety was the only one that did not decrease its instantaneous carboxylation efficiency $(A / C i)$, even under severe stress (Fig. 3e). On the hand, the RB72454 variety was the most affected, with 94\% reduction when under severe water stress.

The primary photosynthetic capacity, Fv/Fo, remained unchanged only in RB92579 and RB931011 varieties when stress was imposed. Among varieties, RB72454 had the highest Fv/Fo under control conditions and was the one that most reduced $\mathrm{Fv} / \mathrm{Fo}$ under severe stress conditions, with reduction of $87 \%$ (Fig. 3f).

Principal component analysis showed that varieties were grouped according to each water treatment (Fig. 4b and d). $C i$ was more correlated with RB931011 and RB72454 varieties in the control treatment, while under severe stress, was negatively correlated with RB92579 and RB72910 varieties (Fig. $4 \mathrm{a}$ and b). In addition, $g s, \mathrm{E}, \mathrm{Fv} / \mathrm{Fo}$ and $A$ had positive relationship with RB855536, RB92579, RB99382 and RB72910 varieties under control conditions, and negative with RB931011 and RB72454 varieties under severe stress. 


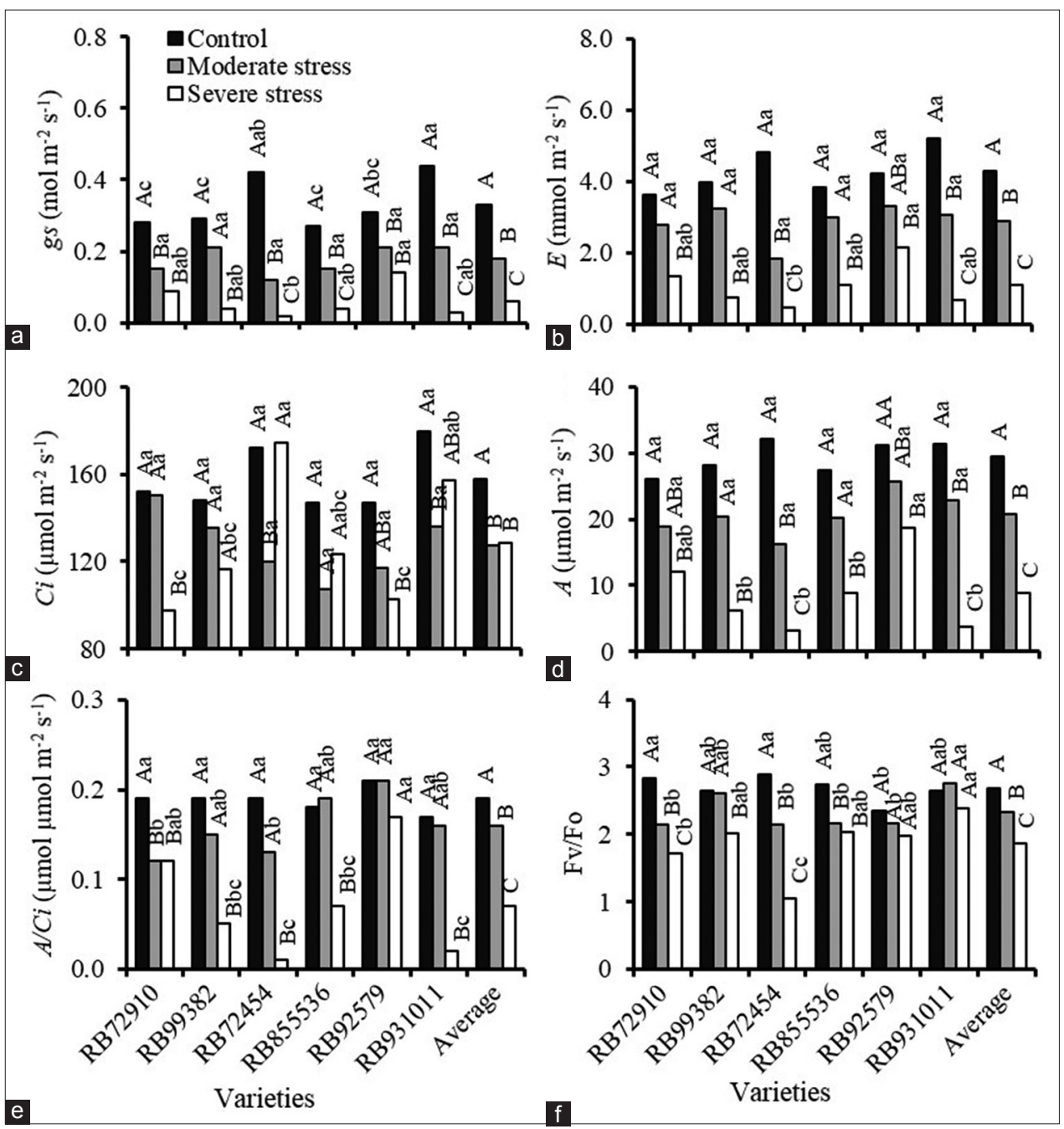

Fig 3. Stomatal conductance (a), transpiration (b), internal CO2 concentration (c), photosynthesis (d), carboxylation efficiency (e) Primary photochemical efficiency of photosystem II, Fv/Fo (f) in sugarcane varieties under different water treatments: control, moderate stress and severe stress. Different capital letters indicate significant differences between water treatments in each variety; different lowercase letters indicate significant differences between varieties in each water treatment by Tukey test $(p<0.05)$.

Table 3: Summary of the analysis of variance of morphological variables: plant height (PH), leaf number (LN), leaf length (LL), leaf width (LW), leaf area (LA), specific leaf area (SLA), leaf dry biomass (LM), stalk dry biomass (SM) and shoot dry biomass (LM+SM) in sugarcane varieties under different water treatments: control, moderate stress and severe stress

\begin{tabular}{lcccccc}
\hline SV & DF & \multicolumn{5}{c}{ Mean squares } \\
\cline { 2 - 6 } & & PH & LN & LL & LW \\
\hline W & 2 & $92716.12^{*}$ & $264.93^{*}$ & $37.72^{\text {ns }}$ & $8.93^{*}$ & $48125813.34^{*}$ \\
V & 5 & $2097.55^{*}$ & $1.08^{*}$ & $406.78^{*}$ & $2.39^{*}$ & $2135651.80^{*}$ \\
(W x V) & 10 & $791.00^{*}$ & $1.58^{*}$ & $152.82^{\text {ns }}$ & $0.30^{*}$ & $727307.03^{*}$ \\
Error & 51 & 319.69 & 0.44 & 42.95 & 0.08 & 123714.48 \\
\hline & & SLA & LM & SM & (LM+SM) \\
\hline W & 2 & $42.09^{\text {ns }}$ & $300289.14^{*}$ & $27917.82^{*}$ & $509096.51^{*}$ \\
V & 5 & $158.22^{*}$ & $32529.86^{*}$ & $770.06^{*}$ & $39373.41^{*}$ \\
(W x V) & 10 & $166.58^{*}$ & $9222.04^{*}$ & $641.32^{*}$ & $13353.98^{*}$ \\
Error & 51 & 37.91 & 179.96 & 46.34 & 262.00 \\
\hline
\end{tabular}

SV: Sources of variation; DF: degrees of freedom; W: Water treatments; V: Varieties. *: significant at $\mathrm{P}<0.05$ by Tukey test; ns: non-significant

\section{Biometric changes}

Varieties plant morphology respond differently to drought stress, which can be seen by the significant interaction among factors in almost all biometric variables (Table 3), only leaf length was not affected by the water treatments.
Plant height differed among varieties when under control and moderate stress, but there was no difference when under severe stress (Fig. 5a). While, leaf number significantly decreased under severe stress, with RB931011 variety being the most affected, with reduction of $65.2 \%$ (Fig. 5b). 


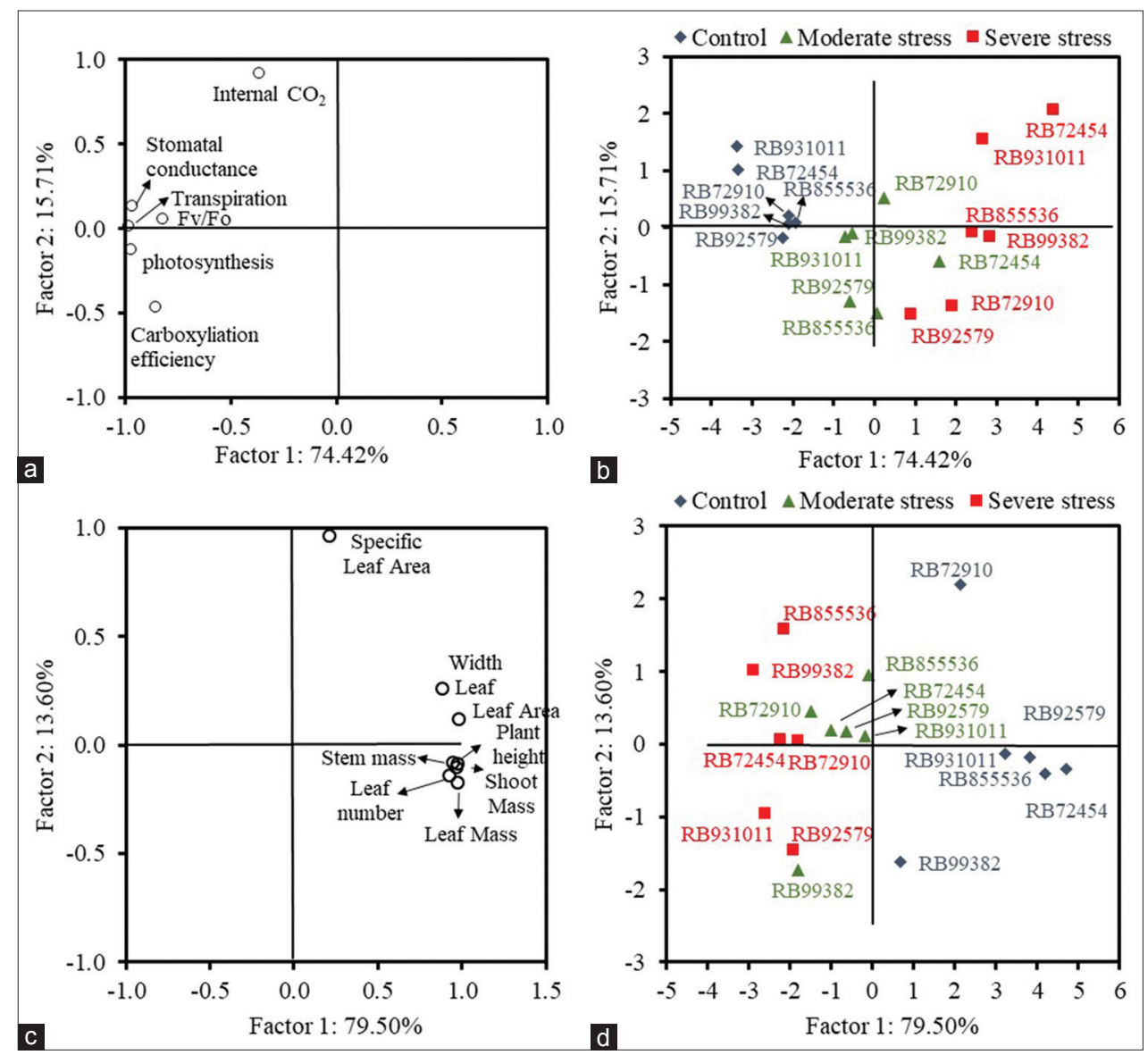

Fig 4. Principal Component Analysis of physiological changes ( $a$ and $b$ ) and biometric $(c$ and $d)$ in sugarcane varieties under different water treatments: control, moderate stress and severe stress.

All varieties had reductions in leaf width, especially RB72454 variety, which reduced $41.1 \%$ (Fig. 5c), while length was not affected by water stress (Fig. 5d). The leaf area of sugarcane decreased $47.7 \%$ under moderate stress and 65.5\% under severe stress. The RB931011 and RB72910 varieties were the most and least affected by water stress, respectively (Fig. 5e). In the same way, leaf thickness was also affected by drought stress, as can be seen by the decreased specific leaf area by approximately 30\% in RB72910 and RB92579 varieties under severe stress (Fig. 5f).

The total leaf mass was severely affected by severe stress, mainly in RB72454 and RB855536 varieties, with mean reduction of $67.7 \%$ and $75.3 \%$, respectively, in relation to control plants (Fig. 6a). Similar results were observed in stalk mass, in which RB855536 and RB72454 varieties had the highest stalk mass when under adequate water conditions, but were the most affected by water stress (Fig. 6b). Under moderate stress, these varieties had stalk mass reduction of 75 and 61\%, respectively, while under severe stress, reduction increased to $81.5 \%$ in RB72454 variety. This also affected the shoot mass, which was dramatically affected by severe stress, with higher reductions in RB72454 variety, $77.9 \%$, followed by RB855536 variety, 71.3\% (Fig. 6c).

Principal component analyses showed that plant height, leaf width, leaf number, leaf area, dry leaf mass, dry stalk mass and dry shoot mass were related to RB72454, RB855536, RB931011 and RB92579 varieties under control treatment, while specific leaf area was related to RB72910 variety (Fig. 4c and d). However, under severe stress, plant height, leaf number, leaf mass, stalks and shoot had little relation to RB99382, RB72454 and RB931011 varieties.

\section{DISCUSSION}

The leaf water potential $(\Psi \mathrm{w})$ reflects the water tension in the leaf, whose gradients direct the flow of water from the plant to the atmosphere, and has been widely used in studies of water stress effects on plants (Bergonci et al., 2000). The RB 72454 variety had the lowest $\Psi_{\mathrm{w}}$ when under drought stress, which may indicate greater dehydration of protoplasts, leading to a greater reduction of $g s, E$ and $A$ (Endres et al., 2010; Silva et al., 2013). In sugarcane under different irrigation regimes, leaf $\Psi_{\mathrm{w}}$ increased 


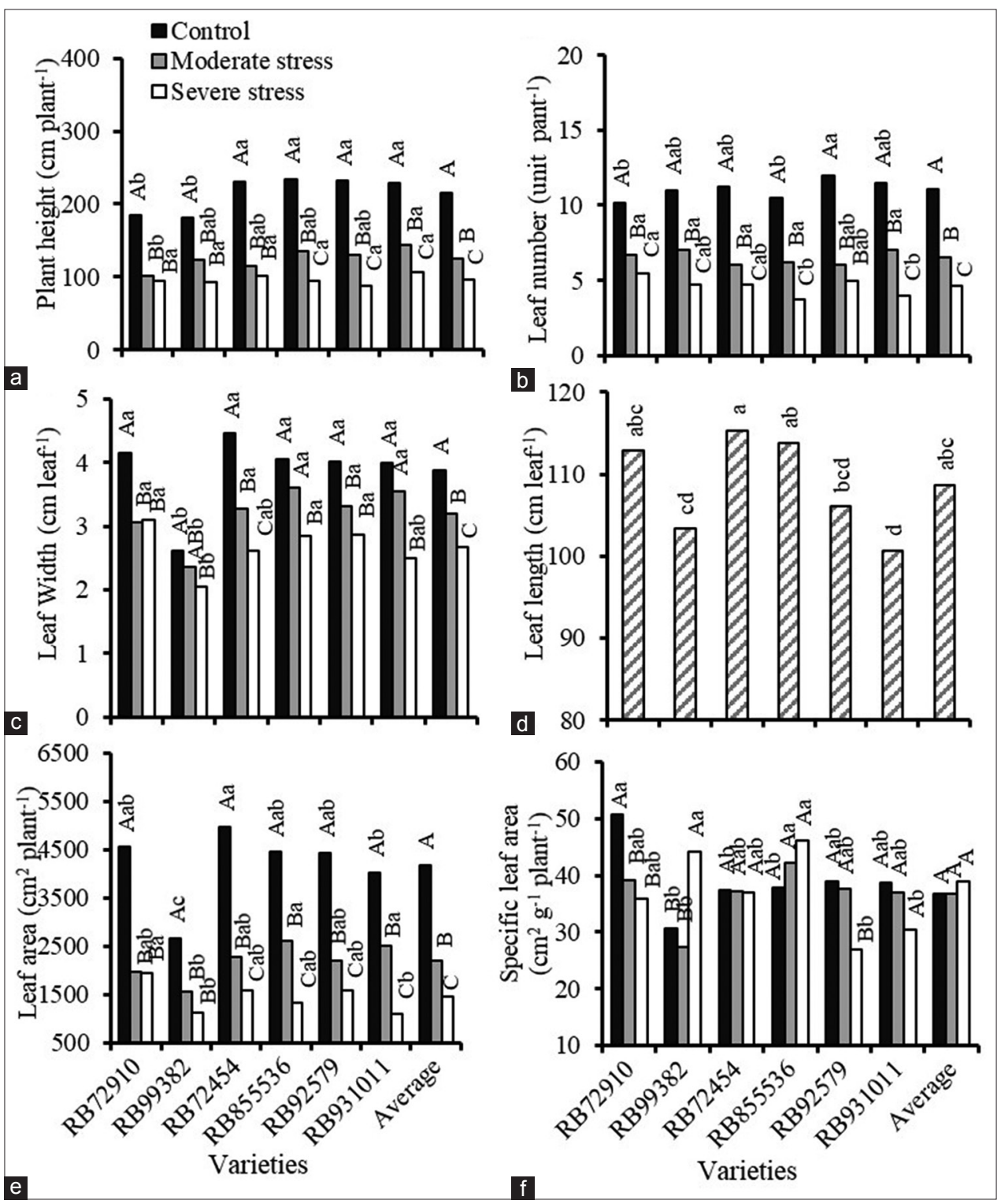

Fig 5. Plant height (a), leaf number (b), leaf width (c), leaf length (d), leaf area (e) and specific leaf area (f) in sugarcane varieties under different water treatments: control, moderate stress and severe stress. Different capital letters indicate significant differences between water treatments in each variety; different lowercase letters indicate significant differences between varieties in each water treatment by Tukey test $(p<0.05)$.

proportionally to the increase in water supply, indicating that with low leaf $\Psi_{\mathrm{w}}$ under water-limiting conditions, the crop undergoes greater stress (Vieira et al., 2014). The maintenance of $\Psi_{\mathrm{w}}$ in sugarcane was related to drought tolerance, for maintenance growth in height and production of dry mass of the stalk (Machado et al., 2009).

The reduction in the $\mathrm{Fv}_{\mathrm{v}} / \mathrm{Fo}_{\mathrm{O}}$ ratio is an indicator of structural damage in thylakoids, affecting electron transport, photochemical efficiency and finally $\mathrm{CO}_{2}$ assimilation (Peixoto et al., 2002; Kalaji et al., 2011). These metabolic damages were observed in RB72454 variety, which presented low $\mathrm{Fv} / \mathrm{Fo}$, as also observed in the principal component analysis. In addition, it may interfere with other physiological processes, such as stomatal conductance and photosynthesis (Medeiros et al., 2013; Silva et al., 2013).

In sugarcane, drought stress-sensitive varieties rapidly respond to drought with stomatal closure (Machado et al., 2009; Medeiros et al., 2013). Again, it seems to be the case of RB72454 variety in our experiment, as also observed in a water stress experiment in greenhouse (Gonçalves et al., 2010). Stomatal closure may initially be advantageous, as the plant quickly responds against excessive water loss avoiding leaf dehydration (Machado et al., 2009; Inman-Bamber et al., 2012); however, when prolonged it becomes inefficient, since it ends up by interfering with the diffusive flow of $\mathrm{CO}_{2}$ (Sales et al., 2012; Medeiros et al., 2013). Therefore, it could be inferred that the low 


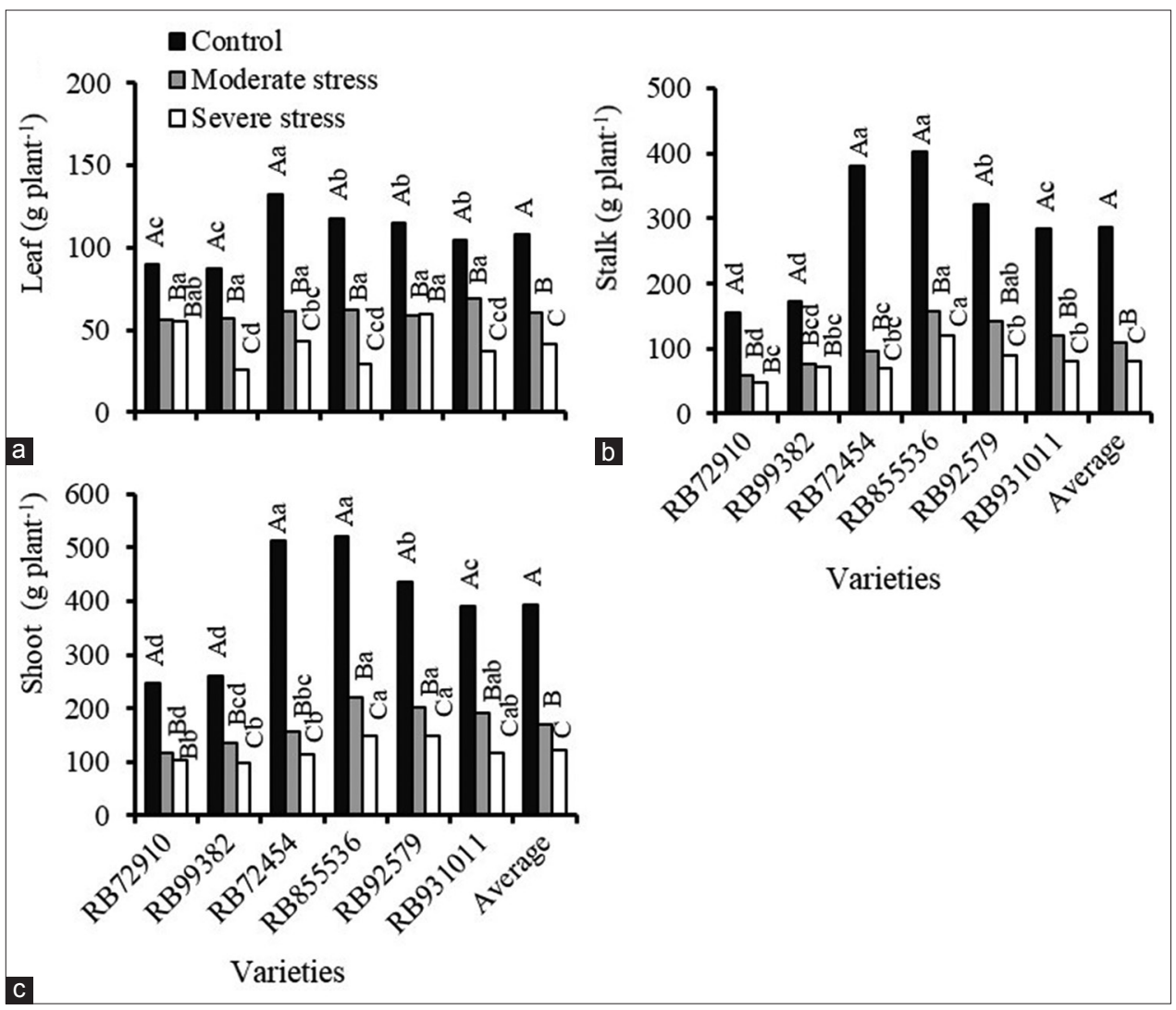

Fig 6. Dry biomass of Leaf (a), stalk (b) and shoot (c) in sugarcane varieties under different water treatments: control, moderate stress and severe stress. Different capital letters indicate significant differences between water treatments in each variety; different lowercase letters indicate significant differences between varieties in each water treatment by Tukey test $(p<0.05)$.

stomatal conductance in RB72454 variety operated as a disadvantageous strategy, making the attempt to save water ineffective, since the variety also had the lowest water potential and photosynthesis.

A different strategy was adopted by RB92579 variety that, even with low leaf water potential, maintained good stomatal conductance, transpiration, photosynthesis and primary photochemical efficiency, in addition good carboxylation efficiency. The maintenance of these characteristic under water stress indicates tolerance to stress (Machado et al., 2009). This may be due to the fact that this variety has a more developed root system as observed in commercial crops. This allows the variety to lower the leaf water potential, keep the stomata more open and keep gas exchanges, even under conditions of moderate drought stress (Endres et al., 2010).

With the reduction of stomatal conductance, it is expected that a reduction of the internal $\mathrm{CO}_{2}$ concentration will also occur if the photosynthetic apparatus was not affected by water stress (Kalaji et al., 2011; Medeiros et al., 2013; Ribeiro et al., 2013). Thus, the increased $C i$ with reduction in photosynthesis at the same time in RB72454 and RB931011 varieties can be attributed to some non-stomatal factor of photosynthesis reduction as water stress became more severe, such as the lack of ATP and NADPH, coming from the electron transport chain of photosystem II, and consequently the reduction of the carbon fixation metabolism (Sales et al., 2012).

The stomatal closure has a strong influence on transpiration and photosynthesis (Medeiros et al., 2013; Silva et al., 2013). The same was found in this study, in which a greater reduction of transpiration and photosynthesis in RB72454 variety and lower in RB92579 variety was observed, following the stomatal behavior. Medeiros et al. (2013) observed that sugarcane varieties more sensitive to drought stress had a strong reduction of transpiration when under water stress, with less intense reduction in more tolerant varieties. These physiological mechanisms, in addition to being interconnected, are quite unequable among sugarcane varieties (Endres et al., 2010; Gonçalves et al., 2010).

Biometric changes are consequences of physiological alterations caused by drought stress (Machado et al., 2009; Pincelli and Silva, 2012). Our study showed that under moderate stress, this characteristic was maintained, but under severe stress, the height differences among varieties do not were significant. In sugarcane under water stress, plant height 
can be used as a criterion in the selection of tolerant varieties, as it is highly responsive to drought stress conditions (Machado et al., 2009). However, if stress is very severe, this parameter becomes inefficient in the selection of varieties more tolerant to drought as we could observe in our experiment.

Leaf number reduced drastically with drought stress in sugarcane. Leaf reduction is a result of leaf senescence and reduced new leaf emerge, being a mechanism to reduce transpiration and metabolic expenditure for tissue maintenance (Smit and Singels, 2006; Scalon et al., 2011). In different sugarcane varieties, Holanda et al. (2014) observed that the reduction of number leaf under water stress was lower in more tolerant varieties. In our study, this characteristic was observed in RB72910 variety, also characterized as drought tolerant in commercial crops, although less productive than modern varieties.

Water stress also affected leaf width, mainly of RB72454 and RB931011 varieties. Pincelli and Silva (2012) did not observe a leaf width pattern of sugarcane varieties that could be related to stress tolerance, but in their experiment they only maintained plants under stress during 56 days. According to Holanda et al. (2014), it takes a long period of stress for biometric changes to become more evident. In our study, as the time of exposure to stress was much longer, it was possible to identify leaf width differences among varieties, suggesting that less reduction of leaf width not only indicates tolerance to drought stress but also favors biomass production.

The reduction in leaf number and size resulted in reduction in leaf area. The greatest reduction in leaf area of RB931011, RB855536 and RB72454 varieties, and lower in RB72910, RB99382 and RB92579 varieties may indicate differences among them in the adaptation to stress. Leaf area is extremely sensitive to soil water conditions, especially in more susceptible varieties (Smit and Singels, 2006; Pincelli and Silva, 2012), in which under conditions of water stress end up by affecting the photosynthetic process, and consequently, biomass production (Machado et al., 2009; Medeiros et al., 2013). In addition, the reduction of the specific leaf area, as observed in RB72910 and RB92579 varieties, indicates a strategy of acclimatization to water stress with greater potential for maintenance of crop productivity. The reduction in specific leaf area in plants under water stress indicates higher leaf thickness, which may help to maintain water in the leaf tissue, therefore, allowing a more favorable response to drought (Lopez et al., 1997; Trujillo et al., 2013).

The RB72454 and RB855536 varieties were the most biomass productive under control condition. However, they are among varieties that most reduced productivity when under drought stress as can be observed by principal component analysis. Similar results were observed in other experiments in which water stress affected biomass production in sugarcane (Machado et al., 2009; Medeiros et al., 2013).

We also observed that varieties that naturally have low biomass production, such as RB72910 variety, also have fewer physiological disturbances and lower yield when under water stress. This is well known in literature, where increased rusticity and stress tolerance leads to decreased growth rate (Scalon et al., 2011). Therefore, RB72910 variety can be a good genetic material in breeding programs to obtain modern varieties that are more tolerant to drought. This is the case of RB92579 variety, which produced well under control conditions and was the one that less reduced the shoots biomass under stress conditions, confirming experiences of commercial crops in which RB92579 variety is one of the most productive under rainfed conditions, and therefore one of the most planted today in Brazil.

\section{CONCLUSIONS}

The strategies used by RB92579 and RB72910 varieties such as lower reductions of gas exchange, and lower specific leaf area under conditions of severe water stress provided better drought tolerance, resulting in a smaller reduction of biomass production. Meanwhile, RB72454 variety, despite being quite productive under favorable conditions, was severely affected by drought stress, with drastic reductions of gas exchange, primary photochemical efficiency and leaf width, resulting in great reduction of biomass production.

These different biometric and physiological behavior of drought tolerance among sugarcane varieties indicate that of gas exchange, leaf width and specific leaf area are quite responsive to changes in soil moisture and can be used to discriminate varieties more tolerant to drought stress.

\section{ACKNOWLEDGMENTS}

The authors would like to thank the National Council for Scientific and Technological Development (CNPq), the Coordination for the Improvement of Higher Education Personnel (Capes), the Sugarcane Genetic Breeding Program (PMGCA/RIDESA/UFAL) and Northeast Bank of Brazil (BNB), for financial support.

\section{REFERENCES}

Bergonci, J. I., H. Bergamaschi, M. A. Berlato and A. O. Santos. 2000. Potencial da água na folha como um indicador de déficit hídrico 
em milho. Pesq. Agropec. Bras. 35: 1531-1540.

CONAB - Companhia Nacional de Abastecimento. 2018. Acompanhamento de Safra Brasileira: Cana-de-Açúcar, v.5Safra 2018/2019, n.1-Primeiro Levantamento, maio/2018. Conab, Brasília, p. 62.

EMBRAPA - Empresa Brasileira de Pesquisa Agropecuária. 1997. Centro Nacional de Pesquisa de Solos, Manual de Métodos de Análise de Solos. $2^{\text {th }}$ ed. Rio de Janeiro, p. 212.

Endres, L., J. V. Silva, V. M. Ferreira and G. V. S. Barbosa. 2010. Photosynthesis and water relations in Brazilian sugarcane. Open Agric. J. 4: 31-37.

Gonçalves, E. R., V. M. Ferreira, J. V. Silva, L. Endres, T. P. Barbosa and W. G. Duarte. 2010. Trocas gasosas e fluorescência da clorofila a em variedades de cana-de-açúcar submetidas à deficiência hídrica. Rev. Bras. Eng. Agríc. Ambient. 14: 378-386.

Hermann, E. R. and G. M. S. Câmara. 1999. Um método simples para estimar a área foliar da cana-de-açúcar. STAB, Açúcar, Álcool e Subprodutos. 17: 32-34.

Holanda L. A., C. M. Santos, G. D. Sampaio Neto, A. P. Sousa and M. A. Silva. 2014. Variáveis morfológicas da cana-de-açúcar em função do regime hídrico durante o desenvolvimento inicial. Irriga. 19: 573-584.

Inman-Bamber, N. G., P. Lakshmanan and S. Park. 2012. Sugarcane for water-limited environments: Theoretical assessment of suitable traits. Field Crops Res. 134: 95-104.

Kalaji H. M., B. K. Govindjee, J. Kościelniak and K. Żuk-Gołaszewska. 2011. Effects of salt stress on photosystem II efficiency and $\mathrm{CO}_{2}$ assimilation of two Syrian barley landraces. Environ. Exp. Bot. 73: $64-72$.

Lopez, F.B., Y. S. Chauhan and C. Johansen. 1997. Effects of timing of drought stress on leaf area development and canopy light interception of short-duration pigeonpea. J. Agron. Crop. Sci. 178: $1-7$.

Machado, R. S., R. V. Ribeiro, P. E. R. Marchiori, D. F. S. P. Machado, E. C. Machado and M. G. A. Landell. 2009. Respostas biométricas e fisiológicas ao déficit hídrico em cana-de-açúcar em diferentes fases fenológicas. Pesq. Agropec. Bras. 44: 1575-1582.

Maxwell, C. and G. M. Johnson. 2000. Chlorophyll fluorescence - A practical guide. J. Exp. Bot. 51: 659-668.

Medeiros, D. B., E. C. Silva, R. J. M. C. Nogueira, M. M. Teixeira. and M. S. Buckeridge. 2013. Physiological limitations in two sugarcane varieties under water suppression and after recovering. Theor. Exp. Plant. Physiol. 25: 213-222.

Peixoto P. H. P., F. M. da Matta and J. Cambraia. 2002. Responses of the photosynthetic apparatus to aluminum stress in two sorghum cultivars. J. Plant. Nutr. 25: 821-832.

Pincelli, R. P. and M. A. Silva. 2012. Alterações morfológicas foliares em cultivares de cana-de-açúcar em resposta à deficiência hídrica. Biosci. J. 28: 546-556.

Puteh, A. B., A. A Saragih, M. R. Ismail and M. M. A. Mondal. 2013. Chlorophyll fluorescence parameters of cultivated (Oryza sativa L. ssp. Indica) and weedy rice (Oryza sativa L. var. nivara) genotypes under water stress. Aust. J. Crop. Sci. 7: 1277-1283.

Ribeiro, R. V., R. S. Machado, E. C. Machado, D. F. S. P. Machado, J. R. Magalhães Filho and M. G. A. Landell. 2013. Revealing drought-resistance and productive patterns in sugarcane genotypes by evaluating both physiological responses and stalk yield. Exp. Agric. 49: 212-224.

Richards, L. A. 1965. Physical conditions of water in soil. In: Black C. A., D. D. Evans, J. L. White and F. E. Clark (Eds.), Methods of Soil Analysis - Physical and Mineralogical Properties, Including Statistics of Measurements and Sampling, pp. 128-152.

Sales, C. R. G., R. V. Ribeiro, D. F. S. P. Machado, R. S. Machado, V. L. Dovis and A. M. M. A. Lagôa. 2012. Trocas gasosas e balanço de carboidratos em plantas de cana-de-açúcar sob condições de estresses radiculares. Bragantia. 71: 319-327.

Scalon S. P. Q., R. M. Mussury, V. L. M. Euzébio, F. M. Kodama and C. Kissmann. 2011. Estresse hídrico no metabolismo e crescimento inicial de mudas de mutambo (Guazuma ulmifolia Lam.). Ciênc. Floresta. 21: 655-662.

Silva M. A., C. M. Santos, M. T.Arantes, M. C. Brunelli and L. A. Holanda. 2013. Respostas fisiológicas de cultivares de cana-de-açúcar submetidas à deficiência hídrica e a reidratação. Rev. Caatinga. 26: $28-35$

Silva, M. A., J. L. Jifon, V. Sharma, J. A. G. Silva, M. M. Caputo, M. B. Damaj, E. R. Guimarães and M. I. T. Ferro. 2011. Use of physiological parameters in screening drought tolerance in sugarcane genotypes. Sugar. Tech. 13: 191-197.

Smit, M. A. and A. Singels. 2006. The response of sugarcane canopy development to water stress. Field Crops Res. 98: 91-97.

Trujillo, I., M. Rivas and M. Castrillo. 2013. Leaf recovery responses during rehydration after water deficit in two bean (Phaseolus vulgaris L.) cultivars. J Plant Interact. 8: 360-369.

Van Dillewijn, C. 1952. Bot Sugarcane. Chronica Botanica. First Edition edition, p. 371.

Vieira, G. H. S., E. C. Mantovani, G. C. Sediyama and F. T. Delazari. 2014. Indicadores morfo-fisiológicos do estresse hídrico para a cultura da cana-de-açúcar em função de lâminas de irrigação. Biosci. J. 30: 65-75.

Vitti, G. C., P. H. C. Luz and W. S. Altran. 2013. Nutrição e adubação. In: Santos $\mathrm{F}$ and A. Borém (Eds.), Cana-de-Açúcar: Do Plantio à Colheita. UFV, Viçosa, BR, pp. 66-92.

Zhao, D and Y. R. Li. 2015. Climate change and sugarcane production: potential impact and mitigation strategies. Int. J. Agron. 2015: $1-10$. 